Discourse and Communication for Sustainable Education, vol. 11, no. 2, pp. 65-84, 2020

\title{
Critical Entrepreneurship Education in General Education and TVET: Two Concepts of Practice in a South African Township
}

\author{
Matthias Forcher-Mayr and Sabine Mahlknecht \\ Ithuba Community Colleges, South Africa
}

\begin{abstract}
This paper examines the dominant approach to entrepreneurship education in the South African education system regarding the crisis of youth unemployment. It draws on the case of the public-school sector, in conjunction with the technical vocational education and training (TVET) subsector of the post-school education sector. The comparison of the entrepreneurship education sector plan for public schools with the discourse on TVET reform shows that entrepreneurship education similarly follows the 'skills perspective' with a dominant focus on the formal economy, which is informed by a humancapital based and productivist approach to education. The authors argue that this understanding of entrepreneurship education employs a too narrow perspective on youth unemployment as it overlooks individual capabilities and agency and can contribute to an experience of youth unemployment as individual failure. The authors expand this argument by suggesting a critical entrepreneurship education approach, which is outlined based on two programmes at primary-school and post-school education (TVET) level in a poor urban area. The authors argue that a critical entrepreneurship education approach contributes to learning for capabilities, social justice and democratic citizenship.
\end{abstract} Key words: critical entrepreneurship education, capability approach, South Africa, school, TVET, entrepreneurship education, youth unemployment.

\section{Introduction}

In this paper we discuss how the notion of entrepreneurship education in the South African public education system is based on a human-capital theory and a productivist perspective. We suggest a critical entrepreneurship education approach as an alternative. South Africa is an upper-middle income country that shows high levels of absolute income poverty (Seekings, 2019). The level of inequality remains one of the highest in the world (Bundy, 2018). The development agenda and related economic policy have both been criticised as neoliberal and for not adequately addressing the socioeconomic challenges of post-apartheid South Africa (Adelzadeh, 1996; Bond, 2000; Narsiah, 2002; Terreblanche, 2002). Seekings and Nattrass (2015, p. 21) argue that its "distributional regime" combines neoliberal and social democratic elements. South Africa has chosen a growth 
path that is intensive in capital and skills, but which has not translated into enough growth, or the kind of growth needed to substantially reduce unemployment (Bundy, 2019, p. 92; Seekings, 2019). The economic needs of poor rural and urban populations are somewhat addressed in terms of distribution, but not in terms of "economic opportunities" (Seekings, 2019, p. 51). Redistribution through the 'social wage' makes provision for vulnerable members of the population through social grants, but neglects unemployed young people. Only the 'cream' of the youth is likely to benefit sustainably from existing supply and demand measures against youth unemployment. Thus, the risk of not, or never, finding formal employment is a very real preoccupation for many young people in South Africa.

Persistent youth unemployment has led the public school education sector to intensify a focus on entrepreneurship education and vocational subjects (Department of Basic Education, 2018a; 2018b). Parallel to this, the post-school education sector has embarked on a reform that includes the TVET sub-sector (Department of Higher Education and Training, 2013). It emphasises skills for formal jobs and the growth of the economy (Ngcwangu, 2015; Akojee, 2016). This supply-side approach to youth unemployment has been criticised for overlooking the structural reasons for unemployment and the individualisation of the challenge, framed as a 'skills shortage' or 'mismatch' on the side of the unemployed (Swanson, 2013; Akojee, 2016; Klees, 2017; Vally, 2020). In addition, the potential role of the informal sector regarding economic inclusion has been largely overlooked (Graham \& Mlatsheni, 2015; Akojee, 2016). Both responses are in line with the National Development Plan, where entrepreneurship education and TVET have been identified as a means of addressing youth unemployment and the 'skills challenge' by equipping young people with skills aimed at formal employment (The Presidency, 2012).

The first part of this paper discusses the prevailing concept and understanding of entrepreneurship education within the South African school system, with special reference to the related sector plan (Blecher, 2019; Department of Basic Education, 2018a; 2020). We argue that entrepreneurship education within the public-school education sector shares a similar perspective with the post-school education (TVET) sector, in that it focuses on skills for jobs in the formal labour market. It is guided by concepts such as 'relevant skills' or 'mindset', and focuses on the needs of the labour market and the economy. With respect to entrepreneurship education, we argue it does not give enough attention to individual capabilities. Instead, it is implied that young people can gain individual skills at school, which lead to jobs or entrepreneurship in the formal economy, regardless of social and spatial inequalities. This can lead to confusion and disillusion on the part of those who remain unemployed, despite them trying hard and persevering. The ability to analyse and understand the impact of individual capabilities and structure on their transition from school to work could help them understand their position and to act upon it.

The second part of this paper discusses an alternative approach to entrepreneurship education, via two programmes for children and youth at a primary school and a skills centre, respectively. Both programmes are run at an independent community college in a poor Johannesburg community, and were locally developed and implemented by the authors. The programmes are informed by an approach to entrepreneurship education that builds on individual capabilities and aims at developing the critical awareness of learners and participants. 
The term 'community college' denotes the focus of the institution. This differs from that of the community colleges arising out of TVET reform and mentioned below. The term 'learners' refers to children and youth at school, while 'participants' is used for young people in the post-school (TVET) sub-sector. In using the term 'post-school education (TVET) system' we refer to the sector of the system "comprising education, training and skills development relating to a wide range of occupational fields, production, services and livelihoods" (UNESCO, 2015, annex II, p. 2). From the perspective of the guiding reform document, the White Paper for Post-School Education and Training, this includes primarily TVET colleges, as well as the new entity of community colleges (Department of Higher Education and Training, 2013). While TVET colleges are linked to the formal economy, the new community colleges will be geared towards a more developmental perspective (Akojee, 2016). In this paper, we refer only to TVET colleges, as the establishment of community colleges has not yet had an impact.

\section{Skills and Entrepreneurship (Education) for the Formal Sector?}

After 1994, South Africa emerged from an educational system in which one of the key objectives was the systematic disempowerment of 'black' learners (Harley \& Wedekind, 2002; Lemon, 2004; Meny-Gibert, 2018). Today, the public education system remains burdened by this legacy. The public-school system faces challenges regarding infrastructure, quality of teaching and learning, safety and spatial inequality. Learning outcomes have been criticised (Wolhuter, 2014; Spaull, 2015). The post-school education (TVET) system shares most of these challenges. In addition, relevance is an area requiring improvement (Akojee, 2016). Entry, curriculum requirements and finance form barriers to young people. Dropout rates are high (Branson, Hofmeyr, Papier, \& Needham, 2015). Regarding its reform, the concepts of employability and responsiveness to the formal labour market are central to the debate (Wedekind, 2012; Department of Higher Education and Training, 2013; Ngcwangu, 2015, Heasly et al., 2020). Attempts at reform mainly follow a 'skills-for-formal jobs' narrative. This relates to an economic policy that follows a "high productivity, technology-led growth path," which demands skilled labour (Graham \& Mlatsheni, 2015, p. 51). This stands in contrast to the challenges faced by many unemployed youth who have either left under-resourced schools early, or struggle as matriculants to enter or remain in the post-school (TVET) system, or even to find a job with their exit qualification. Reasons for this are institutional as well as connected to a lack of endowments in youths' households (e.g. education, financial, social networks, and formal labour market experience). Post-apartheid geographies feature a dominant spatial disadvantage; young people live far away from quality educational institutions and places of work, which therefore requires time and money to access using public transport. Regarding graduate unemployment, Kraak (2010) points to "the collapse of structured pathways from education into work" and to the lack of social networks amongst "newly graduated Black professionals" (pp. 98-99). Graduate unemployment is not evenly distributed and is particularly high in the TVET college sector. In contrast, elite universities with more white graduates are less affected (Kraak, 2010). Overall, indicators suggest that school-leavers are largely struggling to enter the formal labour market or transition into further training. Of the 19-24 age group ("Bornfree Millennials", 2017), 46.1\% were not in education, employment or training (NEETs) and of these, $40.8 \%$ completed secondary school (Statistics South Africa, 2018, p. 94). 
Overall, youth unemployment is at $69.5 \%$ (age group 15-24, expanded definition) (Statistics South Africa, 2020, p. 41). More than half of the population lives in poverty (Statistics South Africa, 2018, p. 6). A poor quality of education, in combination with the intergenerational transmission of poverty, affects social mobility (Spaull, 2015). At the same time the formal sector does not produce enough employment and is "still an insider club" (Friedman, 2017). Thus, unemployment cannot be remedied by merely 'upskilling' people. A broader perspective on learning is necessary, one that includes a full spectrum of opportunities ranging from finding work in the formal labour market through to the creation of meaningful livelihoods in the informal sector.

Despite evidence of the multifaceted challenges young people face in their transition from school to work, the public education system follows the "dominant economic narrative" (Batjees et al., 2018, p. 155), as laid out in the National Development Plan 2030 and other related policy papers. The NDP emphasises education for skills, innovation and growth-based employment as a priority for progress (The Presidency, 2012). This narrative suggests that "a growing and modernising economy will create jobs and improve lives for all South Africans. Formal education, at the secondary and postschool levels, seeks to prepare youth for entry into this system" (Batjees et al., 2018, p. 155). This discourse is based on a modernist and neoliberal concept of development (Swanson, 2013). It differs strongly from educational concepts of the anti-apartheid movement from the 1970s onwards, which were rooted in ideas of social justice and democratic citizenship (Vally, 2020). Referring to the TVET system, Ngcwangu (2015, p. 26) identifies a narrative that is primarily intended to "serve business and industry interests and to meet the singular interests of a largely unreconstructed labour market." This approach to skills development overlooks structural reasons for unemployment and emphasises a supply over a demand perspective, which asks how work for skills can be created (Klees, 2017). Instead, a "determinism" is employed, which assumes that "education leads to skills, skills lead to employment, employment leads to economic growth, economic growth creates jobs and it is the way out of poverty and inequality" (Klees, 2017, p. 4). In contrast to productivism, a developmental approach emphasises inclusion, social justice and capabilities (Ngcwangu, 2015). This implies that "the role of the formal economy becomes a subset of wider societal perspectives", while the needs of people and communities become the primary focus (Akoojee, 2016, p. 5).

The discourse on skills shortage, or its mismatch, primarily refers to vocational education (Klees, 2017). Entrepreneurship education perpetuates this viewpoint as early as primary school. This holds that young people do not have enough entrepreneurial competences and so must acquire these competences. Both school education and postschool training (TVET) promise formal employment or the prospect of becoming 'entrepreneurs' based on competences. The idea of work in the informal sector as a space for livelihood creation and entrepreneurship is largely missing, despite the reality that many people in South African earn a living in this sector (Branson, Hofmeyr, Papier, \& Needham, 2015; Fourie, 2018). It is therefore not surprising that qualitative data suggests that work in the informal sector is seen as "embarrassing" by youth, and that teachers want 'more' for their learners (Forcher-Mayr, 2014, p. 240-241). If the "official version of social reality" (Baatjes et al., 2018, p. 258) does not come true, i.e. if young people do not manage to find formal employment or start a business, they are less likely to have the analytical perspective with which to make sense of their situation. In such cases, the only apparent explanation is that one has failed to acquire adequate skills. 


\section{What Kind of Entrepreneurship Education?}

Entrepreneurship is a concept that has its roots in the realm of economic activities (Hébert \& Link, 2009). Research on entrepreneurship is a young and developing field (Carlsson, Braunerhjelm, McKelvey, Olofsson, Persson, \& Ylinnenpää, 2013; Faltin, 2018). Entrepreneurship education has been growing since the 1970s in the US, with global interest increasing from about a decade later (Kuratko, 2005; Kirby, 2007). Over time, entrepreneurship education has moved from an emphasis on business venture creation and small business development to a stronger focus on "entrepreneurial skills, attributes and behaviours" (Kirby, 2007, p. 24). Therefore, approaches in entrepreneurship education have widened. Lindner (2018, p. 115) places entrepreneurship education in a societal development context and argues that economy and society are shaped by the actions of citizens "who take an active role". Thus, entrepreneurship education strengthens the individual's ability to act for a "sustainable society". Lackéus (2015, p. 35) notes that entrepreneurship education is still "in a quite early stage of development" and that there is "much confusion amongst various stakeholders" around it. The author suggests the "ability and willingness to create value for other people" (p. 6) as a shared property of different approaches. In his overview of definitions, he identifies a broad spectrum of approaches. These range from a wide approach that focuses on 'practical doing' with a focus on personal development, to a narrower approach with a stronger focus on theory and business orientation. The wider approach dominates within primary and secondary education, with a stronger business focus in respective commercial subjects (Lackéus, 2015). In the European Union, “entrepreneurship”, together with a "sense of initiative", has been defined as a key competency for lifelong learning (EU, 2006, p. 13). At its core, the competency refers to "an individual's ability to turn ideas into action", indicating a wide approach with a focus on society at large (EU, 2006, p. 17). The EntreComp framework translates this definition into a competence framework for teaching and learning. It suggests three competence areas and fifteen entrepreneurship competences, of which only one is concerned with "financial and economic literacy" (Bacigalupo, Kampylis, Punie, \& Van den Brande, 2016, p. 11). In terms of the property of value creation, it builds on the definition of the Danish Foundation for Entrepreneurship - Young Enterprise where it is defined as "financial, cultural or social" (FFE-YE, 2012 , p. 11). From this perspective, entrepreneurship is seen as a wide competence that aims at supporting "personal fulfilment and development, active citizenship [and] social cohesion" (European Union, 2006, p. 13). The fact that this definition is carried by all member states - and the limited number of alternative tangible concepts - gives it a certain reach. Despite its scope, it is linked to an economic rationale that looks at entrepreneurship education programmes through the lens of economic growth. This is seen in the Entrepreneurship 2020 Action Plan of the European Union, which emphasises the need to foster entrepreneurship against the background of the 2008 global economic crisis and identifies it as a "powerful driver of economic growth and job creation" (European Commission, 2013, p. 3). In addition, the plan aims at fostering the employability of citizens. It identifies entrepreneurship education as an area of intervention "to support growth and business creation" (European Commission, 2013, p. 5). Notwithstanding societal scope and the emphasis on non-financial value creation the framework rests on a human-capital perspective. However, it can also provide a practical and theoretical platform for the development of critical and capability-oriented concepts of entrepreneurship education (Forcher-Mayr \& Mahlknecht, 2020a). 
In Africa, entrepreneurship is widely debated as a measure against youth unemployment as documented in a growing body of academic literature and donor publications (Chigunta, Schnurr, James-Wilson, \& Torres 2005; Gough \& Langevang, 2016). This is contrasted by a more limited number of publications on entrepreneurship education.

Globally, comparatively few approaches advocate a perspective that considers individual capabilities and agency to deconstruct the notion of the enterprising self (for example: DeJaghere \& Baxter, 2014). Thus, there is a need for an approach within entrepreneurship education discourse that critically engages with the project of neoliberal hegemony and related strategies, such as self-regulation and optimisation in view of the market, or the individualisation of risk at the expense of becoming an autonomous subject.

The South African national school curriculum (CAPS) introduces entrepreneurship education in grade 7 through the subject Economic Management Sciences (EMS), which spans three grades: 7-9. In this, entrepreneurship education has a strong business focus: "EE content in EMS (...) is mostly theory-based and more slanted towards business management practices with little opportunity to apply their EMS entrepreneurship knowledge in a real-world context" (du Toit, 2016, p. 15). In related learning materials, an entrepreneur is typically an individual "who starts a business" and who is confident, enthusiastic, and/or a risk-taker (Booysen, Bronkhorst, \& King, 2017, p. 82). In higher grades, entrepreneurship education is represented in several subjects across the curriculum with "links to real life learning" (du Toit, 2016, p. 9). Related 'wider' content, in general education subjects such as Life Orientation, is not explicitly connected to entrepreneurship education (Department of Basic Education, 2011b; du Toit, 2016; 2020). Related programmes of varying length and depth supplement formal lessons and are organised at provincial department and individual school levels, in cooperation with NGOs and other providers (North, 2002; Junior Achievement South Africa, 2020).

In addition to existing content across the curriculum, the South African school system has set out to strengthen entrepreneurship in schools, in accordance with the 'Entrepreneurship in Schools' sector plan that was launched in 2018 (Department of Education, 2018a; 2020, p. 13). Entrepreneurship education therefore featured prominently at the annual conference (Lekgotla) of the Department of Basic Education in 2019 and 2020. E3 (Entrepreneurship', 'Employability' and 'Education') is the entity which implements the plan. E3 proposes a wide approach to entrepreneurship education, as it targets subjects across the curriculum and states examples of learner activities that include non-financial value. Overall, an action-oriented and project-based approach to entrepreneurship education is highlighted (Blecher, 2019). The rationale for entrepreneurship in schools is linked to youth unemployment, low levels of entrepreneurial activity, youths' dependence on "social welfare", as well as the call of the National Development Plan 2030 to foster entrepreneurship education at school (Department of Basic Education, 2018a; 2020, p. 13; Blecher, 2019). The stated goal is that "100\% of school leavers in South Africa will be motivated and empowered: 1) continue studying (Education); 2) get a job (Employability); or 3) start their own ventures (Entrepreneurship)" (Department of Basic Education, 2020, p. 47). Entrepreneurship is seen as "key" to South Africa growing "its GDP, (...) to reduce poverty, (...) to reduce unemployment, (...) to boost the economy" (Blecher, 2019, p. 23). The ecosystem intended to support entrepreneurship includes government (through "policy funding support"), teacher training (through changing or enhancing the role of teachers) and business (through partnerships). Further- 
more, civil society is listed (Blecher, 2019, p. 32). The "theory of change" assumes that entrepreneurship education will lead to a new breed of citizens who are either studying, finding employment or who will "start their own enterprise" (Blecher, 2019, p. 7).

This approach suggests a lack of the 'relevant' skills, employability and low entrepreneurial activity as predominant reasons for youth unemployment and entrepreneurship education is presented as the solution. Other than the need to improve the quality of basic education, the complex reasons for unemployment are overlooked. This is an understanding of entrepreneurship education that emphasises the development of entrepreneurial properties of the individual and individualises the challenge of youth unemployment. Such a perspective, which highlights individual skills and attitudes but does not take asset-related and contextual factors into account, is particularly problematic in a highly unequal country such as South Africa. It is misleading for young people, as it excludes a capability perspective on entrepreneurial action and suggests that individual factors such as perseverance, creativity, risk-taking, as well as skills (e.g. planning, financial) alone can lead to a successful livelihood. It operates under the assumption of a 'space of equal possibility', in which everyone has access to the same opportunities and takes the same risks. This perspective ignores the social and economic reality facing the majority of young people in South Africa, who are affected by a highly unequal endowment and risk base, as well as a social, economic and political order that favours those who possess assets. Instead of addressing this reality, this approach asks learners to "change their current 'mindset'. This will further equip learners to become job creators, rather than just mere job seekers and will prepare them for the world of work" (Department of Basic Education, 2018a, p. 61).

Employability is another desired outcome of the sector plan. As such, the plan focuses on the competences of learners and thus individualises employability. This onesided use of the concept burdens youth with the responsibility of achieving the property of employability. Several authors have argued that employability is not solely an individual achievement, but includes a broader range of factors which are outside the control of young people or an educational institution (Guilbert, Bernaud, Gouvernet, \& Rossier, 2016). MacQuaid \& Lindsay (2005) suggest that the concept goes beyond the "employability skills" of the individual and includes "demand side factors" as well (p. 197). Thus, a broader approach should include: (1) "individual factors" alongside, (2) "personal circumstances", and (3) "external factors" (p. 209). When confronted with the living conditions of most unemployed South African youth, this version of employability points towards the impact of personal circumstances and external factors on the ability to find a job.

A human capital-oriented perspective on entrepreneurship education overlooks the social, economic and spatial conditions in which the majority of young South Africans live, attend school or training, and attempt the transition to work. As such, they do not have the freedom to identify - let alone pursue - the opportunities open to a minority of youth who live in better-off households. Young people are called upon to become entrepreneurial and contribute directly to the tackling of the threefold challenge of inequality, poverty and unemployment, which directly affects and constrains them. In claiming that young people must develop more entrepreneurial skills and attitudes, this perspective does not adequately acknowledge young people's individual competences and agency in navigating the difficult transition from school to work against the back- 
ground of existing structures of the education system and the labour market. In a previous study, interviews with young men in an urban township revealed the central importance of education and work in their narratives of becoming an adult (Forcher-Mayr, 2014). Finding work that provides an income, security, purpose and recognition was seen as a key challenge. The experience of chronic unemployment surrounding them led male youth to reflect on their future and the risk of failing to reach normative markers of adulthood and the recognition attached to it. They understood the significance of resources, and employed strategies regarding further education or work in the future. These included a personal risk assessment based on observations around them, planning based on resources, anticipation of success factors, strategic job-seeking, as well as reflecting on and dealing with their own confidence levels. Most importantly, their understanding of individual structural disadvantage and marginalisation led them to develop a conscious and planned approach to mitigate their risk of chronic unemployment.

In the remainder of this paper, the authors argue that where entrepreneurship education is defined as the ability to creatively develop ideas that create financial or non-financial value, it can strengthen young people. Competences that support this kind of action can lead to value creation in the field of civil society by organising political interest groups; by founding cultural, social, educational or other initiatives in the community; by pushing environmental efforts in the neighbourhood and beyond; or by starting or contributing to a business or non-profit organisation. However, such projects cannot evolve in a neutral space where individual capabilities are either equal or are not relevant. To 'undertake something', one needs to take existing endowments (financial, human, political, natural, physical, social), factors of support and constraint (personal, social, political, economic, natural), as well as individual agency and values into account. Such a capability approach to entrepreneurship education is based on the works of Amartya Sen and others. Gries and Naudé (2010) have discussed entrepreneurship through the lens of the capability approach and DeJaeghere and Baxter (2014) did the same regarding entrepreneurship education with reference to sub-Saharan Africa. Sen (1997, p. 18) defines capabilities as people's potential choices or freedoms to achieve - to "lead the kind of lives they value - and have reason to value". Freedoms are viewed as the "principal means" and "primary ends" of development (Sen, 1997, p. 10). The capability approach defines development as a process of removing unfreedoms and looks at "what people can do" (Robeyns, 2005, p. 104).

Considering the above discussion, we advocate a concept of entrepreneurship education that can critically examine the unequal landscape of opportunity and risk, from the perspective of young people. It considers individual capabilities and critical awareness and follows an enquiry-based approach. Inspired by Freire (2005, p. 86) a "problemposing education" perspective examines 'achievable freedoms' and the structural reasons for their limits in order to "overcome [a] false perception of reality". This capabilitybased and critical approach to entrepreneurship education starts at the level of the household, school or the community through life-world- and action-oriented projects, and follows an "action-reflection" approach (Freire, 2005, p. 88). The implementation of capability-based entrepreneurship education programmes includes both a financial value creation perspective that focuses on business or non-profit development, and a wider perspective interested in social, cultural, ecological and civic value creation. Following the properties of critical education, this aims to contribute to the development of self- 
determination, co-determination and solidarity (Klafki, 1996). Thus, entrepreneurship education projects that examine and deconstruct discourses and structures shaping young people's realities through the praxis of action and reflection can contribute to the development of critical consciousness and action for more sustainable economic development, social justice and democratic citizenship.

\section{A Local Concept of Practice}

This section discusses two entrepreneurship education programmes for different target groups. The programmes are situated at primary school level and post-school (TVET) level in the same independent community college in Katlehong township, $30 \mathrm{~km}$ south-east of the Johannesburg CBD. The college is registered as an NGO and includes a primary school, skills centre and community outreach programme. The catchment area of the college is a marginalised peri-urban area. Many households have rural links. The settlement comprises a combination of formal and informal housing. Since 2018, large social housing sites ('RDP-houses') have been developed on additional land or through the upgrading of previously informal sites, leading to a growing local population. For the most part, formal employment opportunities are far away from people's area of residence, resulting in some households' activity in the informal sector. As in other similar areas, poverty and unemployment are major challenges, with social grants contributing to household incomes. Some households face food insecurity. Public schools in the area experience pressure from a growing population of learners, leading to the establishment of temporary container schools. Many local schools' classrooms are overcrowded. From a post-school (TVET) perspective, there are few offerings for out-of-school youth, with no skills centre in the area. Further away, a formal TVET college campus offers courses with a high entry threshold with regard to formal qualifications, fees, duration and curricula.

The community college's educational concept and its offerings are informed by the economic, educational and spatial circumstances of its catchment area. Its programmes aim to reflect the local context and seek to be implementable in under-resourced institutions. Syllabi development builds on the national public-school curriculum (CAPS) and the debate regarding challenges in the post-school (TVET) sector. In 2015, the college adopted a focus on critical entrepreneurship education that follows a capability-based approach. Since 2017, the primary school's agriculture programme ("Sprouting Entrepreneurs") has been adopted by the public education sector on a provincial level, through its implementation in selected public schools in the Eastern Cape and Gauteng (ForcherMayr \& Mahlknecht, 2020a).

The school: This is a primary school (grade 1-7), and follows the national CAPS curriculum. The latter has been described by teachers at the college as prescriptive, content-based and closely monitored by public school authorities at district level. As a result, teachers are anxious to fulfil the requirements, which contributes to a dominant practice of teacher- and test-centred teaching of the formal curriculum. Available schoolbooks support such a practice. Integrated project-based learning with an open outcome, as suggested by the national entrepreneurship education sector plan, is therefore perceived by many teachers as a practice that endangers their likelihood of covering the official curriculum (Department of Basic Education, 2018a). 


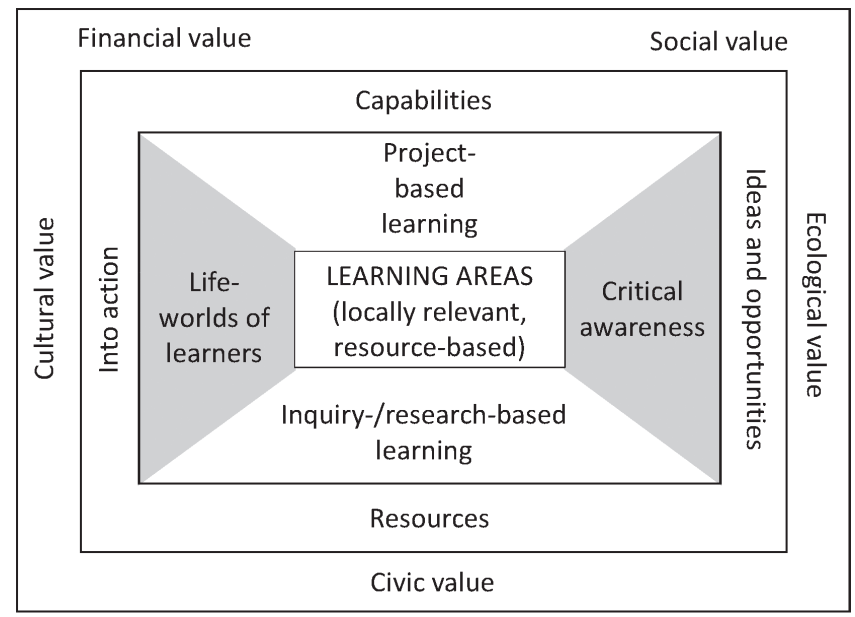

Figure 1. An integrated approach to critical entrepreneurship education (author's graphic)

To overcome the subjective, as well as objective, limitations of curriculum delivery, and to enrich the learning offering without adding pressure to teachers' curricular work, the college has developed an extracurricular learning programme. This centres on critical entrepreneurship education, in conjunction with practical 'doing', and focuses on learners from grade 5 to 7 . The programme consists of the four learning areas of Agriculture \& Food, Sewing \& Creative Arts, Dance and ICT (Figure 1). This selection seeks to cover a spectrum of interests and learning areas that have local relevance, and is based on the availability of teachers and community members able to facilitate and teach these learning areas. The programme curriculum consists of elements of the national CAPS curriculum, but does not follow a strict subject or discipline-related approach. For example, Agriculture \& Food centres on the school-based Entrepreneurship Learning Garden and integrates content from subjects such as the Natural Sciences, Economic Management Sciences, Social Sciences and Geography, Creative Arts and Life Orientation (Forcher-Mayr \& Mahlknecht, 2020a). Based on legal and didactical considerations, learning follows a team-teaching approach, with a team consisting of a practitioner (practical skills) and a teacher (general education). This allows for the learning of a skills component and the integration of learning content from national CAPS curriculum subjects. By learning through community challenges, the representation of learners' life-world is strengthened, and an alternative construction of social reality is enabled. Learning is connected to the social conditions that contribute to young people's understanding of who they are.

The skills centre: This offers post-school learning opportunities to out-of-school youth from the local community. Participants typically have little-to-no experience of post-school education. The majority is unemployed, some have never been in formal employment, and many have only ever worked in various 'piece jobs'. Often, they are the parents or legal guardians of learners in the adjacent primary school. In developing the skills centre, we sought to avoid creating an accredited system with entry barriers, static content and standards devised to lead to jobs in the formal economy, as this does not serve the needs of most potential participants. In contrast, we aimed to develop a system that invites them to participate based on their previous experiences and interests, and which allows for dialogue on content, and individualisation in the development of 
a learning path. Moreover, learning tries to focus on the real capabilities of participants with a view to value creation at a community level. Our perspective is mirrored by what Baatjes et al. (2018, p. 225) have coined "learning to make a life", an approach which is based on extensive consultation with poor and working-class communities in South Africa regarding their experiences with the South African post-school education (TVET) system. The authors argue that this system aims to make people employable through integration into the formal economy. However, many people have experienced their formal education as "irrelevant", "frustrating" and alienating, making them feel "as if they have failed" (Baatjes et al., p. 192). Based on people's perceptions of the formal education system and their lived experiences, the authors advocate an approach to learning that focuses on "meaningful activities", on basic needs, relationships in the family and community and "making a good life" (Baatjes et al., p. 187).

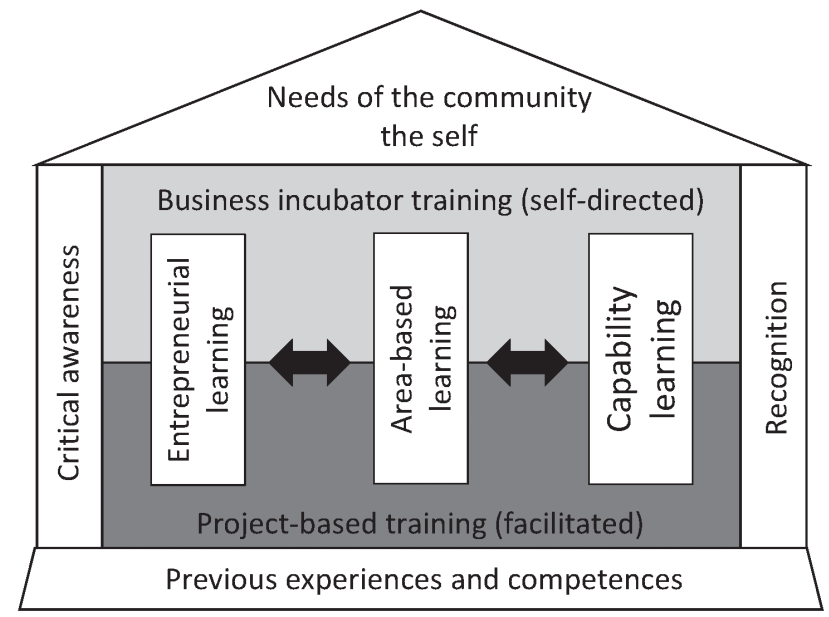

Figure 2. Skills centre training concept (author's graphic)

In addition, our approach builds on the concept of recognition that has been broadly used in the context of social (dis-) integration over the last three decades (Sitzer \& Wiezorek 2005). To be recognised as part of a community and society is a human basic need and mode ("modus") of integration. Thus, the feeling of not being recognised can be viewed as the subjective experience of social disintegration (Kaletta, 2008, p. 207). Heitmeyer \& Anhut (2008) have linked different dimensions of integration to specific forms of recognition. Integration and therefore feelings of recognition are based on employment, housing, consumption and political participation, as well as personal acceptance within a social group. Learning in the skills centre therefore aims to address the dimension of recognition by focusing on 'making a life'. It seeks to enable participants to develop activities and build a meaningful livelihood based on their capabilities, within the community and beyond.

The centre's offering is informed by the specific needs of its target group and the landscape of the post-school education system. It offers four different areas of learning and interest. These build on an approach that asks what people need, want and perceive as useful within a community, as well as the availability of resources and skills to offer the training (Table 2). The courses were developed based on the principle of dialogue, 
in which the interests and perspectives of the participants provide the reference point for action. The courses offer training in the four learning areas of Bricklaying, Sewing \& Fashion Design, ICT (computer applications) and Woodwork. As an example, the Sewing \& Fashion Design learning area is divided into two phases: firstly, a structured phase of ten months introduces participants to the relevant knowledge and skills of the field while learning through projects; secondly an additional elective phase of six months in the business incubator, where participants have access to a workspace, individual coaching and additional, more focused training. There, they can develop a business idea, product and a network of suppliers and customers. Learning is geared towards the informal sector of the community. However, the entrepreneurial goal of value creation is understood as a broad concept that emphasises the equal significance of non-financial value. From a recognition perspective, training is also understood as a 'stepping stone', which strengthens participants' ability to pursue further training or to search for employment elsewhere. Capability-based entrepreneurial learning is integrated into area-based learning (Figure 2).

\section{Teaching Critical Entrepreneurship Education}

Critical entrepreneurship education at both the school and skills centre emphasises a perspective on individual capability through which endowments, structures of support and constraint as well as agency can be examined. The approach is operationalised by combining the competence areas of the EntreComp framework with the capability approach translated into a competence area (Forcher-Mayr \& Mahlknecht, 2020a). In the current absence of contributions to 'critical entrepreneurship education', we label our approach in this way as it resonates with a critical pedagogy and "critical perspectives on entrepreneurship research” (Tedmanson, Verduyn, Essers, \& Gartner, 2015, p. 531). Critical pedagogy is interested in relationships of power and hegemonial interests regarding education (Bernhard, Rothermel, \& Rühle, 2018, p. 16). In the field of critical entrepreneurship research, concern has been raised regarding the overrepresentation of privileged entrepreneurs, the essentialisation of white and male entrepreneurial figures, the support of a hegemonial capitalist narrative and the idealisation of failure (Olaison \& Sørensen, 2014; Verduijin, Dey, Tedmanson, \& Essers, 2014). However, in this paper we do not provide an outline of a comprehensive concept, but rather a theoretically enriched illustration of a locally implemented concept of practice. The outlined capability perspective in entrepreneurship education provides an analytical lens at the level of the individual, the household and the local community

Entrepreneurial learning at school and in the skills centre is not divided into subjects but broader areas of learning, and follows a practical and holistic approach that emphasises continuity. Following John Dewey (2008), it aims at building on the individual and local experiences of learners and participants and their corresponding interests and needs. It views action - which for Dewey includes reflection and verbal communication - as the basis of experience and understanding, which thus informs future action. Learning as a group through local and community-based challenges resonates with Dewey's notion of education for democracy (Beckett, 2013; Tillmann, 2015; Engelmann, 2019, ForcherMayr \& Mahlknecht, 2020b). From a Freirean perspective, learners and participants develop critical consciousness by acting and reflecting on local challenges, which they 
explore through projects and 'a thematic focus' is developed through dialogue. While a particular area of exploration is determined by the programmes' learning areas, it is the learners'/participants' views that form the content of the dialogue, which is directed towards an understanding of the world and the dismantling of - with Freire - oppression (Beckett, 2013).

Table 1

Examples: Types of Value Creation Projects

\begin{tabular}{|c|c|c|}
\hline & Primary school & Skills centre \\
\hline Civic & $\begin{array}{l}\text { Research on community-based challenges } \\
\text { affecting youth. Presentation and discus- } \\
\text { sion at a community hall meeting. }\end{array}$ & $\begin{array}{l}\text { Engagement with challenges facing } \\
\text { small businesses on ward level } \\
\text { [smallest administrative unit]. }\end{array}$ \\
\hline Cultural & $\begin{array}{l}\text { Establishment of a drama \& dance group } \\
\text { that includes a focus on societal challenges. }\end{array}$ & $\begin{array}{l}\text { Establishment of a community- } \\
\text { based reading and debate club on } \\
\text { social and economic issues. }\end{array}$ \\
\hline Ecological & $\begin{array}{l}\text { Mapping \& public presentation of litter } \\
\text { zones in the community. Design and } \\
\text { building of bins out of upcycled materials. }\end{array}$ & $\begin{array}{l}\text { Launch of a community-based } \\
\text { cleaning campaign. Engagement with } \\
\text { ward committee on future action. }\end{array}$ \\
\hline Financial & $\begin{array}{l}\text { Investigation into reasons for unhealthy } \\
\text { eating within in the community. Sale of } \\
\text { self-grown vegetables on market day. } \\
\text { Provision of information regarding } \\
\text { healthy eating to customers. }\end{array}$ & $\begin{array}{l}\text { Establishment of a small business } \\
\text { or cooperative. }\end{array}$ \\
\hline Social & $\begin{array}{l}\text { Inquiry into the reasons for food insecurity } \\
\text { within the community. Production and } \\
\text { distribution of self-grown vegetables as } \\
\text { parcels and seedlings to food-insecure } \\
\text { households. }\end{array}$ & $\begin{array}{l}\text { Establishment of a community } \\
\text { training garden with plots and child- } \\
\text { care for participants. Engagement } \\
\text { with ward committee regarding } \\
\text { support measures. }\end{array}$ \\
\hline
\end{tabular}

The capability approach provides the framework through which inquiry/researchbased learning is conducted. Inquiry informs this approach, as well as the entire learning process, as it focuses on the following aspects (Forcher-Mayr \& Mahlknecht, 2020b): (1) the challenges, needs and opportunities within a community, as well as the social, economic and political order in which these play out; (2) methods of enquiry and research such as interviews, structured observation, community mapping; (3) reflection on the development of specific competences in a learning area; and (4) reflection on one's own learning path. 'Critical awareness' is two-fold: it refers to the understanding of opportunities and constraints within a project, and it focuses on reflection on the social, economic and political order, which is experienced through an ongoing engagement in learning challenges grounded in the reality of the community. Experience results from 'doing' and forms the basis of future action.

Two examples shall illustrate this:

1. The school - in the learning area of Agriculture \& Food, the challenge of food insecurity, which affects almost one-fifth of South African households (Statistics South Africa, 2017), is identified and investigated by learners. By investigating what households in the community mean when they speak of "having enough food" vs. "not having enough food", learners gain an understanding on a community level (Forcher-Mayr \& Mahlknecht, 2020b). In subsequent steps, this can be contrasted 
with spatial differences in food insecurity through a combination of personal accounts, community mapping conducted by learners, and learning materials that provide a socioeconomic perspective. Subsequent practical garden projects can aim at contributing to food security (e.g. assisting vulnerable households in establishing homebased gardens or the production and distribution of seedlings), while reflecting critically on the challenges of such initiatives (Table 1).

2. The skills centre - in the learning area of Sewing \& Fashion Design, participants conduct research to identify needs and opportunities within the community, develop an idea and work on it. For example, according to research, sun hats for toddlers appear as a business opportunity. Implementation must include consideration of demand, profitability and place of sale. At the same time, possible restrictions on the production and sale of such a product to the community, given available capabilities, should be discussed. If participants find that certain products they could produce are offered at a cheaper rate by large producers and their retailers, reasons for this are investigated and discussed. Inquiry is supported by a facilitator and relevant materials that support analysis and discussion. In this way, alternative opportunities are explored in critical consciousness of structural constraints. These two examples follow the Freirean idea of a shared investigation by learners/ participants and teachers/facilitators, so that they examine the reality in which they seek to develop and implement ideas (Beckett, 2013).

Table 2

Skills Centre: Critical Entrepreneurship Education Connected to Learning Areas

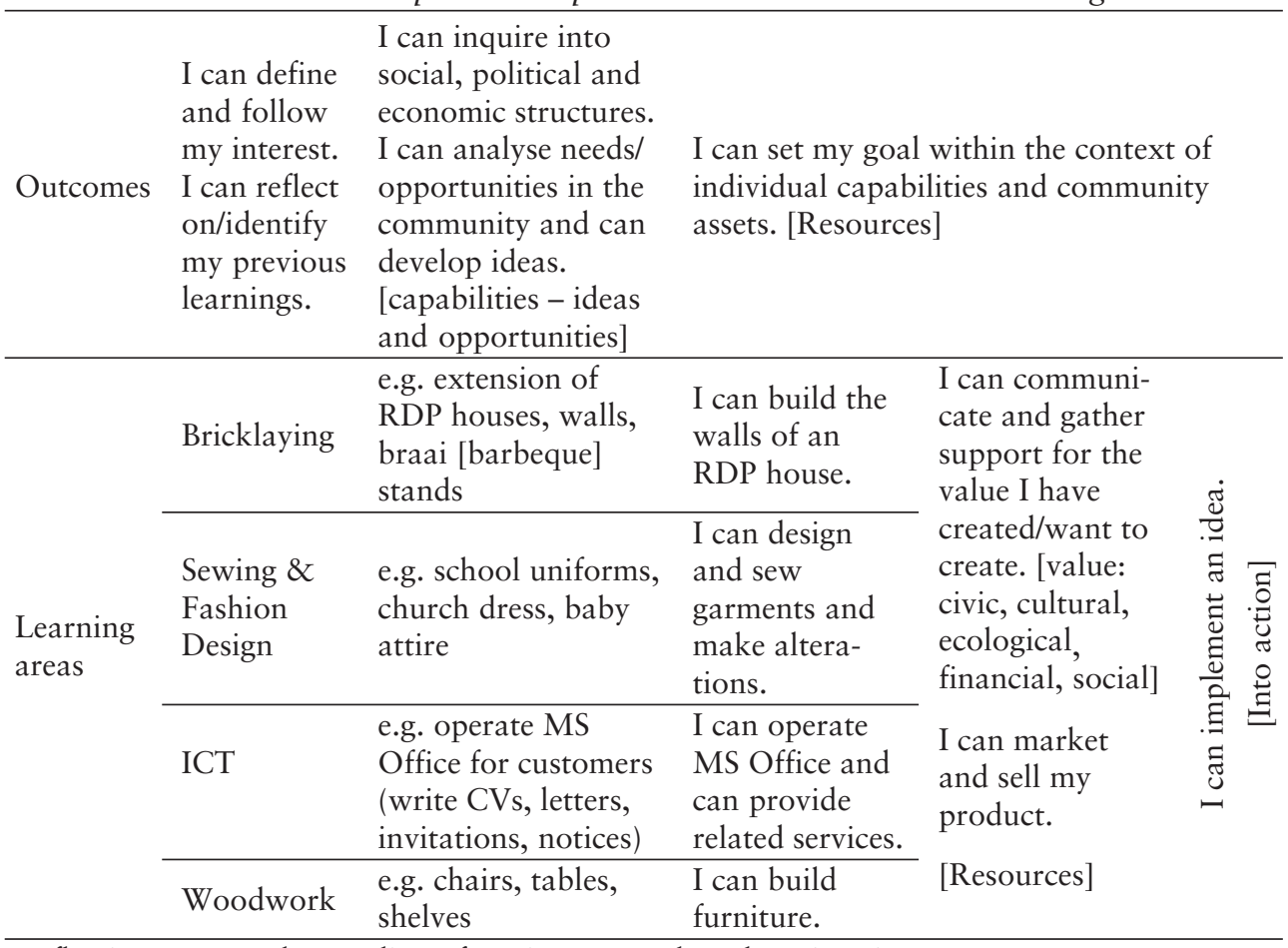

Reflection My understanding of my interest and my learnings improves as I progress. 


\section{Conclusions}

In this paper, we have examined the dominant approach to entrepreneurship education in the South African public-school sector and its relation to the skills perspective within the post-school education and training (TVET) subsector. We have criticized the skillsfor-formal-work orientation of entrepreneurship education and its disregard to the capability deprivations of the majority of unemployed youth. This was contrasted with the advocated approach of a critical entrepreneurship education.

The assumption, that attaining skills for the formal labour market will lead to employment, economic growth and social inclusion, underlies the dominant skills discourse. It has been described as a human capital theory-based and productivist perspective. The current sector plan to strengthen entrepreneurship education in the public-school system follows this discourse. Entrepreneurship education is positioned as a response to the challenge of youth unemployment, which is defined through the properties of 'lack of skills' and 'lack of employability' with a view to inclusion in the formal sector. We have argued that this perspective overlooks the complex causes of youth unemployment in South Africa and a broader approach to social inclusion. Rather than starting with the capabilities of young people and their household within a community context, this view confines them into 'a supply-side perspective' according to which they have to acquire relevant skills, the properties of an employable person and an entrepreneurial mindset in order 'to fit' the demands of the labour market. In addition, it calls upon young people to contribute to the tackling of developmental challenges as entrepreneurs. From the perspective of critical pedagogy, which calls for the development of self- and co-determination, an important component of a liberating and humanising education is overlooked.

The local concept of practice presented in this paper emphasises the critical examination of capabilities, by asking what young people are free to achieve. Entrepreneurship education is defined as the ability to turn ideas into action through which civic, cultural, ecological, financial or social value for others is created. Challenges within learning areas are developed in dialogue with learners and participants. Through 'doing' in projects, young people investigate the landscape of opportunities and needs at a school, household or community level, against the background of available assets, enabling or constraining factors, as well as values and agency. This perspective aims to deconstruct the notion of the learner/participant as an enterprising self, and emphasises that the constitution of opportunities and related ideas is connected to factors that often can lie beyond individual control. In focusing on real challenges in the community, learning connects to the lifeworld of learners/participants and allows for the deconstruction of a dominant narrative according to which schooling, post-school education and hard work provide a safe passage into formal employment.

We suggest critical consciousness as a distinct goal of entrepreneurship education. A perspective that seeks to empower young people to identify opposing interests, power, and hegemonial narratives on various levels of society should be an important element in learning through, for and about entrepreneurship. It can thereby assist in identifying discursive and actual practices of placing societal challenges at young people's doorsteps through the individualisation of structural challenges. To act upon this is one avenue of value creation. The development of a critical pedagogy perspective within entrepreneurship education - translated into a didactical framework - therefore appears as an important field of future research, as well as teaching and learning at schools or in post-school (TVET) institutions. 
Author's note:

The authors are seconded to Ithuba Community Colleges on behalf of the Austrian Federal Ministry of Education, Science and Research (BMBWF).

\section{References}

Adelzadeh, A. (1996). From RDP to GEAR: The gradual embracing of neo-liberalism in economic policy. Transformation, 31, 66-95.

Akojee, S. (2016). Developmental TVET rhetoric in-action: The White Paper for postschool education and training in South Africa. International Journal for Research in Vocational Education and Training, 3(1), 1-15.

Baatjes, I. (Ed.). (2018). Learning for a living: Towards a new vision for post-school learning in South Africa. Cape Town: HSRC press.

Bacigalupo, M., Kampylis, P., Punie, Y., \& Van der Brande, G. (2016). EntreComp: The entrepreneurship competence framework. Luxemburg: Office of the European Union.

Beckett, K. S. (2013). Paulo Freire and the concept of education. Educational Philosophy and Theory, 45(1), 49-62.

Bernhard, A., Rothermel, L., \& Rühle, M. (2018). Einleitung [Introduction]. In Bernhard, A., Rothermel, L., \& Rühle, M. (Eds.), Handbuch Kritische Pädagogik [Handbook of critical pedagogy] (pp. 11-23). Weinheim \& Basel: Beltz.

Blecher, T. (2019). E3 entrepreneurship and employability education (presentation at $\mathrm{E}^{3}$ conference and writer's workshop, 26.-28.04.2019, Pretoria). Retrieved from https://www.education.gov.za/E3EntrepreneurshipConference.aspx

Bond, P. (2000). Elite transition: From apartheid to neoliberalism in South Africa. Scottsville: University of Natal Press.

Booysen, W., Bronkhorst, J., \& King, S. (2017). Oxford successful economic management sciences grade 7 learner's book (18 ${ }^{\text {th }}$ ed.). Cape Town: Oxford University Press Southern Africa.

Branson, N., Hofmeyr, C., Papier, C., \& Needham, S. (2015). Post-school education: Broadening alternative pathways from school to work. In Lannoy, A. D., Swartz, S., Lake, L., \& Smith, C. (Eds.), South African Child Gauge 2015 (pp. 42-49). Cape Town: Children's Institute, University of Cape Town.

Bundy, C. (2019). Post-apartheid inequality and the long shadow of history. In Soudien, C., Reddy, V., \& Woolard, I. (Eds.), State of the nation: Poverty \& inequality: Diagnosis, prognosis, responses (pp. 79-99). Cape Town: HSRC Press.

Carlsson, B., Braunerhjelm, P., McKelvey, M., Olofsson, C., Persson, L., \& Ylinnenpää, H. (2013). The evolving domain of entrepreneurship research. Small Business Economics, 41(4), 913-930.

Chigunta, F., Schnurr, J., James-Wilson, D., \& Torres, V. (2005). Being “real” about youth entrepreneurship in Eastern and Southern Africa: Implications for adults, institutions and sector structures (SEED working paper no. 72). Geneva: International Labour Organization.

De Jaeghere, J., \& Baxter, A. (2014). Entrepreneurship education for youth in subSaharan Africa: A capabilities approach as an alternative framework to neoliberalism's individualizing risks. Progress in Development Studies, 14(1), 61-76. 
Department of Basic Education (2011a). Curriculum and assessment policy statement grades 7-9. Economic Management Sciences. Pretoria: DBE.

Department of Basic Education (2011b). Curriculum and assessment policy statement grades 7-9. Life Orientation. Pretoria: DBE.

Department of Basic Education (2018a). Entrepreneurship in schools. Pretoria: DBE.

Department of Basic Education (2018b). Circular S1 of 2018: The incremental introduction of technical occupational subjects as part of the Three Stream Model. Retrieved from https://www.education.gov.za/Portals/0/Documents/Publications/Circular\% 20S1\%20of\%202018.pdf?ver=2018-05-30-140318-717

Department of Basic Education (2020). E3 - entrepreneurship, employability, education (presentation at DG meeting with district directors: Eastern Cape). Retrieved from https://www.education.gov.za

Department of Higher Education and Training (2013). White paper for post-school education and training: Building an expanded, effective and integrated post-school system. Pretoria: DHET.

Dewey, J. (2008). Democracy and education. Radford, VA: Wilder Publications.

Du Toit, A. (2016). Foundations in the South African senior phase curriculum for entrepreneurship education in consumer studies. Journal of Family Ecology and Consumer Sciences, 44, 11-20.

Du Toit, A. (2020). Entrepreneurship education: Equipping learners with knowledge and skills for a changing world (presentation at the Basic Education Lekgotla, 15.17.01.2020), Johannesburg.

$\mathrm{E}^{3}$ (2020). Entrepreneurship, employability and education - the $E^{3}$ solution (presentation at the Basic Education Lekgotla, 15.-17.01.2020), Johannesburg.

Engelmann, S. (2019). Lernen zwischen Freiheit und Zwang [Learning between freedom and un-freedom]. In Eck, S. (Ed.), Forschendes Lernen - Lernendes Forschen [Research-based learning - learning in research]. Weinheim \& Basel: Beltz Juventa, 16-32.

European Commission (2013). Entrepreneurship 2020 action plan: Reigniting the entrepreneurial spirit in Europe. Brussels: EC. Retrieved from https://eur-lex. europa.eu/legal-content/EN/TXT/PDF/?uri=CELEX:52012DC0795\&from=EN

European Union (2006). Recommendations of the European Parliament and of the council on key competences for lifelong learning. Brussels: Office Journal of the European Union.

Faltin, G. (2018). Entrepreneurship: Problemlagen und Handlungsansätze [Entrepreneurship: Problems and courses of action]. In Faltin, G. (Ed.), Handbuch Entrepreneurship [Handbook entrepreneurship]. Wiesbaden: Springer, 3-36.

FFE-YE (2012). Impact of entrepreneurship education in Denmark - 2011. Retrieved from www.ffe-ye.dkImpact

Forcher-Mayr, M. (2014). Fragile Übergänge. Junge Männer, HIV/AIDS und Gewalt [Fragile transitions. Young men, HIV/AIDS and violence]. Innsbruck: Innsbruck University Press.

Forcher-Mayr, M., \& Mahlknecht, S. (2020a). A capability approach to entrepreneurship education: The Sprouting Entrepreneurs programme in rural South African schools. Discourse and Communication for Sustainable Education, 11(1), 119-133. 
Forcher-Mayr, M., \& Mahlknecht, S. (2020b). Entrepreneurship Learning Gardens und forschendes Lernen. Das Beispiel ländlicher Schulen in Südafrika [Entrepreneurship Learning Gardens and research-based learning. The example of rural schools in South Africa]. Transfer Forschung - Schule: Forschendes Lernen (6) (A. Eghtessad, Th. Kosler, \& C. Oberhauser, Eds.) [Transfer research - school: research-based learning, 6] (pp. 212-224). Klinkhardt.

Fourie, F. (2018). Enabling the forgotten sector: Informal-sector realities, policy approaches and formalisation in South Africa. In Fourie, F. (Ed.), The South African informal sector: Creating jobs, reducing poverty (pp. 439-478). Cape Town: HSRC Press.

Freire, P. (2005). Pedagogy of the oppressed (30 ${ }^{\text {th }}$ anniversary Ed.). New York \& London: Continuum.

Friedman, S. (2017). The ANC isn't ready to radically transform the South African economy. Retrieved from https://theconversation.com/the-anc-isnt-ready-toradically-transform-the-south-african-economy-75004

Gough, K. V., \& Langevang, T. (2016). Introduction: Youth entrepreneurship in subSaharan Africa. In Gough, K. V., \& Langevang, T. (Eds.), Young entrepreneurs in sub-Saharan Africa (pp. 1-11). New York.: Routledge.

Graham, L., \& Mlatsheni, C. (2015). Youth unemployment in South Africa: Understanding the challenge and working the solutions. In De Lannoy, A., Swartz, S., Lake, L., \& Smith, C. (Eds.), South African Child Gauge 2015 (pp. 51-59). Cape Town: Children's Institute, University of Cape Town.

Gries, T., \& Naudé, W. (2010). Entrepreneurship and human development: A capability approach (WIDER working paper, No. 2010/68). Helsinki: The United Nations University World Institute for Development Economics Research.

Guilbert, L., Bernoud, J. L., Gouvernet, B., \& Rossier, J. (2016). Employability: Review and research prospects. International Journal of Educational and Vocational Guidance, 16, 69-89.

Harley, K., \& Wedekind, V. (2004). Political change, curriculum change and social formation, 1990-2002. In Chisholm, L. (Ed.), Changing class: Education and social change in post-apartheid South Africa (pp. 195-220). Cape Town: HSRC Press.

Heasly, B., Lindner, J., Iliško, Dz., \& Salìte, I. (2020). From initiatives, to insights, to implementation of the sustainability and securitability agenda for 2030. Discourse and Communication for Sustainable Education, 11(1), 1-4.

Hébert, R. F., \& Link, A. N. (2009). A history of entrepreneurship. London \& New York: Routledge.

Heitmeyer, W., \& Anhut, R. (2008). Disintegration, recognition and violence: A theoretical perspective. New Directions for Youth Development, 119, 25-37.

Johnson, W. R. (1982). Education: Keystone of apartheid. Anthropology \& Education Quarterly, 13(3), 214-237.

Junior Achievement South Africa. (2020). Our programmes. Retrieved from https://jasa.org.za/programmes/

Kaletta, B. (2008). Anerkennung oder Abwertung. Über die Verarbeitung sozialer Desintegration [Recognition or degradation. On the subjective reflection of social disintegration]. Wiesbaden: VS Verlag für Sozialwissenschaften.

Kirby, D. (2007). Changing the entrepreneurship education paradigm. In Fayolle, A. (Ed.), Handbook of research in entrepreneurship education (pp. 21-45). Cheltenham: Edward Elgar. 
Klafki, W. (1996). Neue Studien zur Bildungstheorie und Didaktik [New studies on the theory of education and didactics] ( $5^{\text {th }}$ ed.). Weinheim and Basel: Beltz.

Klees, S. J. (2017). Beyond neoliberalism: Reflections on capitalism and education. Policy Futures in Education, 0(0), 1-21.

Kraak, A. (2010). The collapse of the graduate labour market in South Africa: Evidence from recent studies. Research in Post-Compulsory Education, 15(1), 81-102.

Kuratko, D. F. (2005). The emergence of entrepreneurship education: Development, trends, challenges. Entrepreneurship Theory and Practice, 29(5), 577-597.

Lackéus, M. (2015). Entrepreneurship in education: What, why, when, how (entrepreneurship 360 background paper). Paris: OECD.

Lemon, A. (2004). Redressing school inequalities in the Eastern Cape, South Africa. Journal of Southern African Studies, 30(2), 269-290.

Lindner, J. (2018). Entrepreneurship education for a sustainable future. Discourse and Communication for Sustainable Development, 9(1), 115-127.

McQuaid, R. W., \& Lindsay, C. (2005). The concept of employability. Urban Studies, 42(2), 197-219.

Meny-Gibert, S. (2018). State "infrastructural power" and the Bantustans: The case of school education in the Transkei and Ciskei. African Historical Review, 50(1-2), 46-77.

Narsiah, S. (2002). Neoliberalism and privatisation in South Africa. Geo Journal, 57, 3-13.

Ngcwangu, S. (2016). The ideological underpinnings of World Bank TVET policy: Implications of the influence of human capital theory on South African TVET policy. Education as Change, 19(3), 24-45.

North, E. (2002). A decade of entrepreneurship education in South Africa. South African Journal of Education, 22(1), 24-27.

Olaison, L., \& Sørensen, B. M. (2014). The abject of entrepreneurship: Failure, fiasco, fraud. International Journal of Entrepreneurial Behaviour and Research, 20(2), 193-211.

Robeyns, I. (2005). The capability approach: A theoretical survey. Journal of Human Development, 6(1), 93-114.

Seekings, J., \& Nattrass, N. (2015). Policy, politics and poverty in South Africa. Houndmills: Palgrave Macmillan.

Seekings, J. (2019). Poverty and inequality: South Africa in a continental context. In Soudien, C., Reddy, V., \& Woolard, I. (Eds.), State of the nation: Poverty \& inequality: Diagnosis, prognosis, responses (pp. 42-56). Cape Town: HSRC Press.

Sen, A. (1997). Development as freedom. Oxford: Oxford University Press.

Sitzer, P., \& Wiezorek, C. (2005). Anerkennung [Recognition]. In Heitmeyer, W., \& Imbusch, P. (Eds.), Integrationspotentiale einer modernen Gesellschaft [Potentials for integration in modern societies] (pp. 101-132). Wiesbaden: Verlag für Sozialwissenschaften.

Spaull, N. (2015). Schooling in South Africa: How low-quality education becomes a poverty trap. In De Lannoy, A., Swartz, S., Lake, L., \& Smith, C. (Eds.), South African Child Gauge 2015 (pp. 34-39). Cape Town: Children's Institute, University of Cape Town.

Statistics South Africa. (2017). Towards measuring the extent of food security in South Africa. Pretoria: Statistics SA. 
Statistics South Africa. (2018). Poverty mapping in South Africa. Pretoria: Statistics SA.

Statistics South Africa. (2020). Quarterly labour force survey. Quarter 4: 2019. Pretoria: Statistics SA.

Swanson, D. M. (2013). Neoliberalism, education and citizenship rights of unemployed youth in post-apartheid South Africa. Sisyphus Journal of Education, 1(2), 194-212.

Tedmanson, D., Verduyn, K., Essers, C., \& Gartner, W. B. (2015). Critical perspectives in entrepreneurship research. Organization, 19(5), 531-541.

Terreblanche, S. (2002). A history of inequality in South Africa 1652-2002 (5 $5^{\text {th }}$ ed.). Scottsville: University of Natal Press.

The Presidency (2012). National development plan 2030. Our future-make it work. Pretoria.

Tillmann, A. (2015). Forschendes Lernen im Geographieunterricht [Research-based learning in geography at school]. In Gebhard, U. (Ed.), Sinn im Dialog [Understanding in dialogue] (pp. 235-251) Wiesbaden: Springer.

UNESCO (2015). Proposal for the revision of the 2001 revised recommendation concerning technical and vocational education. Retrieved from https://unesdoc.unesco. org/ark:/48223/pf0000234137

Vally, S. (2020). Between the vision of yesterday and the reality of today: Forging a pedagogy of possibility. Education as Change, 24, 1-22.

Verduyn, K., Dey, P., Tedmanson, D., \& Essers, C. (2014). Emancipation and/or oppression? Conceptualizing dimensions of criticality in entrepreneurship studies. International Journal of Entrepreneurial Behaviour \& Research, 20(2), 98-107.

Wedekind, V. (2012). Towards responsiveness and employability in the FET college sector (LMIP working paper 23), Durban.

Wolhuter, C. C. (2014). Weaknesses of South African education in the mirror image of international educational development. South African Journal of Education, 34(2), $1-25$.

Correspondence regarding this article should be addressed to Matthias ForcherMayr, Ithuba Community Colleges. Email: matthias.forcher-mayr@bildung.gv.at 